\title{
Traumatic Imaginaries and Flowing Tactics: The White Shirt Movement in Taiwan
}

\author{
Fan-Ting Cheng \\ National Taiwan University, Taipei, Taiwan
}

\begin{abstract}
2013 was a year full of trauma and fury for many people in Taiwan. The death of Hung Chung-Chiu, along with a series of events, including the Referendum of Lungmen Nuclear Power Plant and Dapu Incident, triggered the White Shirt Movement led by Citizen 1985. The movement, as the local harbinger of Internet-organized demonstration, performed a novel form of citizen activity, teasing out a protesting guerrilla that tactically networked disempowered and dispossessed subjects. The guerrilla utilized local mediascapes in reacting to official force with its flowing tactics, which signify the ceaseless negotiation, battle, and play between government and citizens. Extending Sue-Ellen Case's notion of horizontal practice of politics and the performative, this paper focuses on the various theatrical elements used in its activities, including environmental theater and social networking, in order to delineate the traumatic imaginaries and flowing tactics embodied by the White Shirt Movement. Working within and against one another, imaginaries and tactics travel back and forth between physical and virtual spaces, constituting the mobility and structure of contemporary protest events.
\end{abstract}

Keywords: traumatic imaginaries, flowing tactics, White Shirt Movement, Taiwan, performance, protest

\section{Introduction}

On July 4th 2013, Hung Chung-Chiu, a 24-year-old Taiwanese corporal in the Army of the Republic of China, was reported dead after being forced to perform vigorous physical training under disciplinary confinement for, according to the Army, illegally bringing a camera phone into the military base. Emerging evidence seems to indicate that a conspiracy between the Kuomintang Government and the military system led to Chung-Chiu's death. His death, however, was swiftly concluded to be accidental. Although Kao Hua-Chu, the current Minister of National Defense, bowed in remorse for Chung-Chiu's death and nominally resigned from office - his resignation was immediately rejected by then President Ma Ying-Jeou — and the Ministry of National Defense promised that the crucial evidence, a defective monitor video tape, would be handed over to the Ministry of Justice Investigation Bureau, Taiwanese activists organized Citizen 1985, an activist organization that aims to unveil and reinvestigate pending criminal cases that occurred within the Republic of China's Army during past several decades. ${ }^{1}$ Later in August, a quarter million people gathered at Ketagalan

Fan-Ting Cheng, Ph.D., Assistant Professor, National Taiwan University.

${ }^{1}$ See Citizen 1985's official website at the following link:

http://pttcitizen1985.blogspot.com/. These cases include the deaths of numerous soldiers including: Lu Mung-Ying, Yao Tai-Yuan, Tsai Hsueh-Liang, Chen Chun-Ming, Hong Wen-Pu, Chiang Kuo-Ching, Huang Kuo-Chang, Ying Ching-Feng, Lei Cheng-Ju, Chiang Ming-Chun, Chen Guang-Che, and many yet unnoticed others. See the list at the following link: http://kissinwang.ezyou.cc/6.shear/Love\%20\&\%20Justice/armykiller.htm. 
Boulevard in front of the Office of the President to protest human rights violations and institutional violence; sadly, however, then President Ma Ying-Jeou, who was also the commander-in-chief, responded ambivalently, providing no substantial response.

In this paper, I examine the White Shirt Movement in order to examine how the event performs what I call the performative practice of protesting, an ongoing political project that ceaselessly reacts and responds to the complex networking between the political/economic apparatus and the media/technology spectacle. Deeply inspired and influenced by protest events abroad, especially Occupy Wall Street and the Arab Spring, the White Shirt Movement highlights how citizens of an unrecognized state can fight for political recognition through networking transnational resources online and offline. Organized online by anonymous Internet surfers, the movement advocates for a political reformation in Taiwan that would purge the stale military system, the remnant of Kuomintang's anachronistic "Reconquering Mainland" project, through a series of small outdoor performances that intertwine well-known local tales with the contemporary tragedy of the Chung-Chiu's death.

In her forthcoming article "Bedding the Horizontal: Entertaining Pleasure in the Permanent Present," Sue-Ellen Case coins the notion of "horizontal practice of politics and the performative" to represent a particular anarchist act of bringing diverse issues and materials together through a lens that "emphasizes inclusion over aim and is co-produced alongside a certain sense of an impasse" (Case, forthcoming, pp. 7-9). The idea of "impasse," which breaks from any utopian sense of time moving toward a future, signifies the scenario of what Case calls "the era of horizontalism" (Case, forthcoming, pp. 7-10; Berlant, 2011, p. 21). Destroying utopian fantasies, the idea of impasse targets totalitarianism in a more flexible way. As current totalitarianism dwells in the rhizomic power apparatus, the mobility of a single, specific direction becomes less useful. Grounding my arguments in Case's theorization of horizontalism, I aim to point out that the horizontal practices of contemporary protesting and performative events underscore a ceaseless and tactical mobility that highlights the complexity of the political/economic milieu. The horizontal practices recognize and demonstrate themselves as long-term, or even never-ending, projects that flexibly and subtly work within and against changing societies. Indeed, they signify an impasse in the sense that they do not point to an imagined future of idealized progression; rather, they highlight the capabilities of accommodating the changing scenarios and launching corresponding tactics. It is this flexibility, continuity, and horizontality that promise a possibly novel way for the politically disempowered and dispossessed subject to fight for social justice.

\section{Theatricality and the Digital}

The movement, up to now, consists of three demonstrations: the Citizen Act Up that took place in front of the National Defense and at the Chang Kai-Shek Memorial Hall on July 20th, The Farewell to Chung-Chiu/ August Snow Movement that took place at Ketagalan Boulevard in front of the Office of the President on August 3rd, and The World is For All that took place right outside of the Legislative Yuan on October 10th, which is the national birthday of ROC. The participators and the organizers of the three demonstrations are commonly called "the White Shirt Army" as most of them follow the dress code of the movement: wearing a white shirt. $^{2}$

\footnotetext{
${ }^{2}$ On the one hand, since the color white does not represent any political party in Taiwan, it avoids bedding the political standpoints of either the Kuomintang or the Minjintang and maintains its focus on the request and petition for political reformations. On the other hand, the color white, which is commonly used in Taiwanese funeral, signifies a grieving for the officially-ungrievable victims suffered from unjust political violence.
} 
Successfully appealing to more than a quarter of a million "White Shirt Soldiers" in barely two weeks, the White Shirt Movement is organized and led by Citizen 1985, an unofficial organization founded by thirty-nine Internet surfers who did not know each other before Chung-Chiu's death. Except Hsiao and Chen, who only give their surnames as identifiable information, members of Citizen 1985 remain anonymous to prevent being arrested by the government, even after organizing three strikingly well-attended rallies. ${ }^{3}$ These members use Internet platforms, especially Facebook and PTT Bulletin Board System, to hold group meetings and to transmit related information that has been purposely censored in particular media such as China Times and Chung Tien News (CTi News). ${ }^{4}$ The information has been widely spread through what local Internet surfers call "lazy people package," usually an assemblage of information, news, documents, images, texts, and other materials related to a certain event or topic. This kind of assemblage is usually produced anonymously to protect himself/herself/themselves from any possible political retaliation. In addition, Internet surfers usually help cover each other if there is any identical information that can be leaked from the packages. Because of its protection mechanism, the packages become a flexible, helpful, and powerful tool for disempowered citizens to work together to highlight the officially erased.

According to Citizen 1985, the name of the organization comes from the Ministry of National Defense's hotline number for filing complaints in the military. Using the hotline, however, requires the caller to report his or her identity, which Citizen 1985 thinks results in military torture and murder. Inspired by the British novelist George Orwell's Nineteen Eighty-Four, anonymous organizers designed the slogan of the movement, which is an image of a bleeding eye with a slogan pairing with it- "The Big Citizen is Watching You" (Orwell, 2013). Orwell's novel presents an imagined superstate of totalitarianism in a world of omnipresent government surveillance and public mind control. Orwellian dominance here becomes a trope of the oppressing Kuomintang regime against which Citizen 1985 demonstrates. Citizen 1985 is said to signify, as Hsiao states, "the epitome of a civilized society." It is purposely designed to operate only online with no physical office or identifiable staff. By maintaining itself an online organization, Citizen 1985 denotes that the offline Taiwanese society has been supervised, controlled, and constructed by an official government of a singular political standpoint.

On the morning of July 20th, approximately thirty thousand demonstrators pack the National Defense Ministry located at the intersection of Aiguo West Road and Bo'ai Road. The demonstration officially started at nine thirty with a silent tribute to Chung-Chiu's death. The tribute is followed by a series of outdoor performances that parody the military totalitarianism and the stale Kuomintang ideology. Scripted and performed by anonymous activists, the performance, Citizen Act Up, presents the ROC military culture. At the plaza in front of the National Defense Ministry, approximately a hundred young men sit with their legs crossed on the tarmac floor. All dressed in white shirts, casual pants with their faces covered by medical gauze masks, the performers show dull and lifeless expressions on their faces. The camouflage pants on some of the performers signify the military setting of the play. A man, in an authoritative and provoking tone of voice, commands the people to perform a series of military exercises, including marking time, pushing-ups, singing military songs, and hooraying for the ROC.

\footnotetext{
${ }^{3}$ The source can be found at the following link: http://www.chinapost.com.tw/taiwan/national/national-news/2013/08/05/385577/Citizen-1985.htm.

${ }^{4}$ Both presses are commonly deemed pan-blue media.
} 
Standing in the horrible heat, usually over 101-Fahrenheit degrees during the daytime in July, the people try hard to perform accurately what the man commands. When performing push-ups, the standing crowd starts to yell and curse in an extremely infuriating tone: "do it, damn stupid soldiers/ fuck ya, you son of a bitch/ do it, you fucking pussy/ are you here for pleasure, you mother fucker," making the scene violent and oppressing. After the exercises, the people perform together the song Fat Cat and Gangsters in a Team adapted from the famous local military song Nine Heroes in a Team - "fuck and beat as you wish/ who cares about the law and the judge" - and ask the Minister of the National Defense Kao Hwa-Chu to "wake up" and "act up." Since conscription works as the main military system in Taiwan, it is usually the military officers convening/commanding the citizens to act up for the country/ROC. The performance, however, subverts the power relationship between the military officers and the common citizens, rendering the officers as convened and commanded by the citizens. In this sense, the citizens challenge the national authority through the use of political parody. The Vice Minister of National Defense finally showed up after the performance, apologizing to all the citizens of Taiwan. Although accepting the petition made by Citizen 1985, the Ministry of National Defense, in the evening of the same day, declared that only Military investigators would investigate Chung-Chiu's death, a group distrusted by most of the citizens. This result led to the second demonstration, even larger and angrier.

In an image of the second demonstration photographed by Jake Sun, it is easy to see the White Shirt Army occupying the intersection of Ketagalan Boulevard and Zhongshan South Road. The white-dressed demonstrators make the intersection look like a colossal white, shiny cross. ${ }^{5}$ This image has been widely distributed, arousing attention from not only domestic, but also international media. Yet, what the image does not capture is the fluidity of the colossal cross, which is embodied by a quarter of a million demonstrators moving around the intersection. These demonstrators do not move toward a specific direction; instead they occupy the spot, as if painting the intersection with the white color of their shirts.

However, it should be noted that this act of occupation is not a still impasse but a flowing movement. The food trucks, polices, celebrities, performances among the crowd make the demonstrators keep moving back and forth instead of stand/sit at the same spot. The demonstrators have to tactically and flexibly move all the time to respond to the changing scenario of the entire event. The cross thus seems like a white river that keeps flowing and spreading along the roads. The "banks" of the "river" drastically dissipate and reassemble, signifying the ceaseless negotiation, battling, and playing between the government and the citizens of the White Shirt Movement. The flowing, spreading "river" thus connotes the oscillations of the power relationship between the government and the citizens. The "river" does not point in a specific, single direction, but rather runs through any accessible alleys, streets, and ways, trying out and searching for possible alternatives to achieve its destination.

While heading nowhere, this "river" manifests what Gilles Deleuze and Felix Guattari term "rhizome." Deleuze and Guattari, point out the arborescence of traditional Western philosophy, which sprouts from a single seed, produces a trunk, ceaselessly braches out yet always points to a supposed origin. They coin the term "rhizome" to address mobilities and multiplicities that have no beginning or end and are "always in the middle, between things, interbeing, intermezzo" (Deleuze \& Guattari, 1987, p. 9). While Shu-Mei Shih and Françoise Lionnet note that Deleuze and Guattari fall back into a recentered model of minor literature because

${ }^{5}$ The image can be easily found online. See image from http://www.ettoday.net/news/20130805/251313.htm. 
the model implies that a minority constructs within a major language, I contend that Deleuze and Guattari's model can be used to importantly highlight the way in which politically-oppressed subjects work within and against the oppressing power(s) (Shih \& Lionnet, 2005, p. 2). Without a specific beginning or ending, the protest is akin to the rhizome, operating "by variation, expansion, conquest, capture, offshoot" (Deleuze \& Guattari, 1987, p. 21). The protest goes on both physically and virtually. It not only manifests a tactical, never-ending power of submission and resistance but also reveals how the power is ceaselessly (re)produced, (re)organized, and (re)narrated through the complex networking of social media and the political and economic apparatuses standing behind them.

The occupy is followed by another performance, which begins with a chorus:

...the injurious insect on the island / the murderer of the crime / who covers up the proof with the military investigators / expert of falsification / dark history and beautified story / the fact is hidden and the truth is destroyed/ are you fooling around the citizens / the one without power is sacrificed/ the spirit of Huang-pu withers in the hell.

On the stage, a performer wears a mask of Tsao Chin-Sheng, the Major General of the National Defense, on his face. Another one wears a camouflage soldier uniform with a big fake monitor installation entirely covering his/her head and a sign stating "there is absolutely no image recorded" in his/her hands. When the host asks for the "general's" opinion on Chung Chiu's death, he fades out for a while and then hysterically repeats "I promise that the ROC army is not that dark;" "No comment;" "there is absolutely no image recorded by the monitor and I do not know why." These sentences represent what Tsao Chin-Sheng said to the journalists in July and August. Parodying Tsao Chin-Sheng's saying, the performer's hysterical repeating claims highlight the absurdity of the whole situation. The performance ends with a demonstrator cursing the injustice of the ROC Military investigators.

Set up as the farewell party for Chung-Chiu, the second demonstration argues for the abolishment of corrupt military investigators, who fail to reveal any proof of crime. Mourning for the dead, many of the demonstrators wear black eye masks with the words "National Defense Cloth" printed on them. The Chinese pronunciation of the word "ministry" is the same as that for the word "cloth:" both pronounced "bu" in Chinese. This cloth implies that the monitor that should have recorded Chung-Chiu's last minutes has been covered on purpose. Paired with the image of the bleeding eye, the "National Defense Cloth" illuminates the constructedness of what one sees in the contemporary world. As the most critical evidence in Chung-Chiu's case, the monitor only provides an "image of darkness" that cannot explain anything (or actually explains everything). The "cloth" thus reveals the way the ruling powers, including the government, institutions, laws, and social norms, construct, dominate, and sustain what the citizens see.

The demonstrators in the "National Defense Cloth" could not see; their eyes are entirely covered up by the cloth that signifies political corruption and the Kuomintang identity that stands behind it. However, the demonstrators see through the mobile devices held in their hands, which constantly records all the details of the demonstration that is more or less erased from the pan-blue media. The mobile devices, including cell phones, cameras, tablet computers, laptops, walkie-talkie, video recorders, voice recorders, and among other various recorders, become digital eyes that support the bleeding "Citizen's eye," gazing at the government through tactical forms of technology. Numerous images, sounds, videos, and other forms of recorded files are circulated and distributed on online forums/platforms such as Facebook and PTT, transmitting and revealing information and news of the officially oppressed demonstration. 
In this light, the second demonstration fashions citizen eyes that are decorporealized, digitalized, and deterritorialized. The covering "National Defense Cloth" claims the malfunction of the corporeal eyes. Since what the citizens see through their corporeal eyes is controlled by the ruling powers, there is no need to entirely rely on these deceived eyes. The functioning mobile devices, effulging among the crowd as dashboard lights of an unknown, huge technologic assemblage, illuminate the overwhelming power of themselves working as digital eyes that replace the corporeal ones. It is the collage of these fragmented recorded files that produces a citizen power, which is ultimately capable of challenging the official dominance and hegemony by revealing that which is covered up.

Now, at the end of 2016, the White Shirt Movement has yet not ended. Citizen 1985 continues forming various protesting events through social media. They have been touring high schools and universities in Taiwan, giving lectures, interviews, performances and workshops to remind of the incompleteness of the amendment to Taiwanese military laws. It should be noted that these events have deeply relied on a special local force in Taiwan: Xiangmin, which usually refers to the unofficial, tactical power organized by anonymous BBS surfers fighting against the official one/government. ${ }^{6}$ Since the government has been generally distrusted by many citizens of the young generations due to recent controversial incidents such as the Referendum of Lungmen Nuclear Power Plant, Parliament Tap Scandal, Dapu Incident, and the signing of the Cross-Strait Service Trade Agreement, BBS has become an accessible forum for the surfers to deliver, share, exchange, and communicate information that is banned, hidden, or ignored by the government and the vested interests. The information does not simply circulate online but also produces political movement offline, transforming virtual power into physical protest.

Xiangmin works as an activist political mob. They are a mob in the sense that they are always not satisfied with the political status quo and are always boldly trying various ways to uncover the covered, empower the disempowered, and judge the officially unjudgeable. As there is neither leader nor any decided, specific unitary goal shared by this mob, the mob works as sets of ongoing tactics that can flexibly transform into different models to cope with and respond to the changing milieu. That said, this is not to say that xiangmin can work as an ideal group of Internet surfers who sort out all cases without bias or benefit. Because of the uncontrollability of xiangmin, it sometimes becomes an extremely violent force that hysterically targets at a specific suspect. While this violence can effectively urge the official to investigate the case and judge without black-box operation, it sometimes violates the suspect's right to privacy by digging out, revealing, and circulating the suspect's personal information inappropriately, even illegally. ${ }^{7}$ Indeed, this violation achieved through powerful social media needs another discussion on privacy, yet it cannot be denied that this violent mob is a necessary product and a needed producer in the Taiwanese context, in which the Kuomintang totalitarianism keeps ghosting the island. The mob signifies the protest flow that I have developed in this paper: a flow that is heading nowhere yet is so tactical and omnipresent that it ceaselessly deterritorializes the official norms. The White Shirt Movement is exactly such a performative event that embodies this survival flow.

\footnotetext{
${ }^{6}$ The term originates from Book of the Later Han written by Fan Ye in the 5th century during the Liu Song Dynasty, meaning village people who lead idle lives and enjoy watching scene of bustle.The term is borrowed and appropriated to describe the BBS surfers and can sometimes be negative as it criticizes those who do not think critically but enjoy participating in the discussion by messing around. See "PTT Chirenlu” (批踢踢奇人錄) included in Pushdoll forum on PTT (推娃版).

7 The local film Silent Code (Lin Shih-Yung, 2012) has interestingly discussed the precariousness of the xiangmin violence.
} 


\section{Conclusion}

By exploring the traumatic imaginaries and the flowing tactics of the events of the White Shirt Movement, I not only intend to highlight the various protest approaches of the movement but also, more significantly, to draw forth a possible minor-transnational networking between these events. Shih and Lionnet note that poststructuralist theories such as Derridean deconstruction, although critiquing the center, seem only to enhance the center when it functions as an end in itself and therefore prevent the reification of the margin (Shih \& Lionnet, 2005, p. 3). They therefore suggest focusing on the connections among different margins, rather than emphasizing the oppositional relationships between the major and the minor. Investigating the events of the movement, it is critical to note the intervulnerability and interdependence not only between each event but also among the events, the social media, and the subcultural contexts. The creative ways the movement flexibly allies with the minority organizations, mostly without any access to the government in power, indeed perform a minor-transnational networking that prompts a possible picture of contemporary protesting performativity. Nevertheless, as flexible and tactical as it may be, this minor-transnational networking does not guarantee for a utopic scenario of protesting.

Judith Butler and Athena Athanasiou stress the fundamental intervulnerability, interrelationality, and interdependence among individuals, groups, states, and other units (Butler, 2013, p. 5). They highlight the double valence of the uprising subject who is always bravely struggling with and fighting against the colossal apparatus, which is produced, sustained, and enlarged by the complex networking between the omnipresent mediascape and political/economic apparatus. By exploring the political potential of the White Shirt Movement, this paper highlights the way in which the activist networks produce and are produced by, incorporate and are incorporated by, transform and are transformed by the complex interplay between political/economic apparatus and media/technology spectacles of the contemporary era. An unambivalent political ideal may not be possible; however a brave, humorous, critical, and perseverant one is possible. I believe it is these political protestors who critically work within and against both the power apparatus and the media/technology scenarios that effectively expedite a world of justice and egalitarianism.

\section{References}

Butler, J., \& Athanasiou, A. (2013). Dispossession: The performative in the political. Malden: Polity Press.

Berlant, L. (2011). Cruel optimism. Durham: Duke University Press.

Case, S. (Forthcoming article). "Bedding the Horizontal: Entertaining Pleasure in the Permanent Present."

Deleuze, G., \& Guattari, F. (1987). A thousand Plateaus: Capitalism and schizophrenia. (B. Massumi, Trans.). Minneapolis: University of Minnesota Press.

Orwell, G. (2013). Nineteen eighty-four. New York: Penguin Press.

Shih, S., \& Lionnet, F. (2005). Minor transnationalism. New York: Duke University Press.

Citizen 1985's official website. (2013). http://pttcitizen1985.blogspot.com/

“39 wangyou faqi taiban molihua geming [39網友發起台版莱莉花革命]” (2013). (39 Surfers Raised Taiwanese Version of Jasmine Revolution). Apple Daily, 21 July. Retrieved 25 September 2016 from http://www.appledaily.com.tw/appledaily/article/headline/20130721/35165187

Li, L. (2013). "Citizen 1985: The mysterious group behind Hung protest” The China Post, 5 August. Retrieved 25 September 2016 from http://www.chinapost.com.tw/taiwan/national/national-news/2013/08/05/385577/Citizen-1985.htm

Zhan, C. (2013). “LíKám Ū Thiann-tióhLán Ê Kua [你敢有聽著咱唱歌]” Youtube, 28 July. Retrieved 25 September 2016 from https://www.youtube.com/watch?v=EmmXB4RLc-M

“25 wan baise shizi xunzhang jingdianzhao chuzi sundawei erzi zhishou [25萬白色十字勳章經典照 出自孫大偉兒子之手]” (2013). (The white-cross picture photographed by Sun Da Wei's son). ETtoday, 5 August. Retrieved 25 September 2016 from http://www.ettoday.net/news/20130805/251313.htm 